\title{
I know who you are, but do others know? Why correct scientific names are so important for the biological sciences
}

\author{
PAT HUTCHINGS H, $^{1 *} \&$ NICOLAS LAVESQUE ${ }^{3,4}$ \\ ${ }^{1}$ Australian Museum Research Institute, Australian Museum, Sydney, Australia \\ ${ }^{2}$ Department of Biological Sciences, Macquarie University, North Ryde 2109, Australia \\ ${ }^{3}$ Univ. Bordeaux, EPOC, UMR 5805, Station Marine d'Arcachon, 33120 Arcachon, France \\ झ"nicolas.lavesque@u-bordeaux.fr, 이ttps://orcid.org/0000-0001-5701-2393 \\ ${ }^{4}$ CNRS, EPOC, UMR 5805, Station Marine d'Arcachon, 33120 Arcachon, France \\ ${ }^{*}$ Correspondence: " pat.hutchings@austmus.gov.au, @ ittps://orcid.org/0000-0001-7521-3930
}

\begin{abstract}
Researchers are continuing to identify polychaetes using inappropriate references and failing to appreciate that many if not most species have restricted distributions. Using Marphysa sanguinea (Montagu, 1813) as a case example, we discuss the loss of valuable data by misidentifying a species. We suggest ways in which this problem can be addressed by both taxonomists, ecologists and other researchers. Furthermore, this situation is not unique to polychaetes but applies to many other groups of marine invertebrates.
\end{abstract}

\section{Introduction}

Biological science uses scientific names to identify organisms and these names are very important because they form the basis for referring to species and they label biodiversity information across the entire spectrum of biodiversity knowledge, from genes to ecology (Thompson \& Pape 2016). This is why it is so important to correctly identify species. We use polychaetes as an example of a diverse group of marine invertebrates that sometimes are incorrectly identified to illustrate the importance of correctly identifying species.

Polychaetes are a diverse and abundant group with over 12,000 described species (Pamungkas et al. 2019) and more species are continually being described. Increasingly, as molecular data become more widely available, we are finding that some widely reported species represent suites of cryptic species (Nygren et al. 2018). Polychaetes are found in a wide variety of marine and estuarine environments and often dominate benthic communities (Hutchings 1998). Indeed, the species diversity or presence of certain species in an assemblage is often used as an indicator of habitat/ecosystem health.

Our knowledge of the taxonomy of polychaetes is largely based on species occurring from the intertidal to shallow subtidal areas, whereas our knowledge of those present in the deep sea is limited (Grassle \& Maciolek 1992, Langeneck et al. 2019). In recent years the unique fauna of deep sea vents and cold water seeps (Goffredi et al. 2017, Menot et al. 2010) and abyssal plains (Glover et al. 2016) has been collected and described, with worms well represented. Also, current projects sampling the abyssal fauna off the east coast of Australia (Gunton et al. in review) and the Clarion-Clipperton Fracture zone (Blake 2019, Bonifacio \& Menot 2019) have revealed a diverse polychaete fauna but such comprehensive surveys are rare. So while this is acknowledged, we also should not underestimate the undescribed diversity in shallow waters even in areas where major studies have been undertaken. For example Fauvel $(1923,1927)$ documented the polychaete fauna of France, but recent studies on one of the major groups, the terebellids, from the same area have shown the presence of many undescribed species (Lavesque et al. 2019a, 2020a, c). We suggest that a similar pattern would be found in all the other groups of polychaetes from this region and also from other parts of the world.

Historically, most polychaete workers were based in northern Europe and worked either on the local fauna or studied collections made during major expeditions such as the Challenger (McIntosh 1885), the Siboga 
(Caullery 1944) and various German based expeditions (Ehlers, 1864, 1887, 1904, 1913). European workers included Augener, Ehlers, Fauvel, Grübe, Hartmann-Schröder, Malmgren, McIntosh and Sars. They described many species from many families and some were later designated by Hartman as the type species of the genus in her Catalogue of Polychaetes (Hartman 1959, 1965).

Only later were polychaetes studied in North America by Treadwell, Verrill in the late $19^{\text {th }}$ and early $20^{\text {th }}$ century and then by Hartman and Pettibone from 1930's to the late 1990's and more recently by Blake, Fauchald, Kudenov and others. So while the polychaete fauna is reasonably well known in northern Europe and America, in many other parts of the world, such as Southeast Asia and India, it is poorly known. Comprehensive studies require active workers such as those now found in Brazil (e.g., Fukuda, Lana, Nogueira, Zanol) and Australia (e.g., Glasby, Hutchings, Kupriyanova, Paxton, Wilson).

With the advent of molecular studies, suites of species are increasingly being described from what was assumed to be one widely distributed species. Nygren et al. (2018) for example found more than 25 species of Terebellides (Trichobranchidae) of which only seven were formally described. This followed a study that clarified the concept of the genus with a redescription of the type species T. stroemii Sars, 1835 and designation of a neotype (Parapar \& Hutchings 2014). The remaining 18 species from North East Atlantic waters (ranging from the British Isles in the south, to the Polar Basin in the north) still need to be formally described based on morphological data. These studies allowed Lavesque et al. (2019a) to clarify the number of species of this genus occurring in French waters, with the only previously recorded species, $T$ stroemii not found during extensive sampling around the French coast. So, currently eight (new) species of this genus are known to occur in this area. Fauvel (1927) does not give precise localities of the material he examined, so probably T. stroemii does not occur in France as the type locality is southern Norway. Moreover, Fauvel (NL, pers. comm.) did not routinely deposit specimens he observed in museums collection. Some of his material is lodged in the Musée Océanographique de Monaco, which do not loan material and do not have their collections databased.

\section{Issues facing polychaete taxonomists}

\section{a. Lack of precise documentation of type location and deposition of type material}

As postulated by Blake (2015), even in the relatively well-known waters of northern Europe and North America, many polychaete species still remain to be described. An additional complication is that many earlier workers failed to designate a type and deposit it in a museum or in many cases gave imprecise type localities or provided few details concerning the habitat in which found. For examples, Eupolymnia trigonostoma (Schmarda, 1861) was described from New South Wales (which has a coastline of $\sim 1300 \mathrm{~km}$ ), Australia, and Sternaspis scutata (Ranzani, 1817) described from off the coast of Turkey, without any precise localities provided. Fabricius in his Fauna Groenlandica (1780), described several species but without any place names (Read, pers. comm.). For example, Capitella capitata (Fabricius, 1780) was described from a place a priori near the present community of Paamiut on the Frederikshåb peninsula (SW Greenland) (Blake 2009).

Additionally, early descriptions are often basic compared to modern ones, yet many were subsequently designated as the type species of a genus. Gradually, these species are being revisited and fully described (Zhang et al. 2019) and in many cases a neotype is designated (Hutchings \& Karageorgopoulos 2003; Blake 2009; Parapar \& Hutchings 2014). This often requires extensive searching of museum collections and assistance by Collection Managers to interpret where these early workers collected their material. In some cases, this involves checking handwriting on original labels and comparing specimens with the original description in terms of size etc, with the aim of identifying which specimens they actually examined to make their descriptions.

So while this quest is the aim of many researchers undertaking major taxonomic revisions, other users of species names like benthic ecologists, physiologists, managers, geneticists, invasive species biologists for example will certainly have different priorities.

\section{b. Lack of taxonomic knowledge and relevant regional keys}

Lack of taxonomic knowledge and appropriate keys is a major issue for these researchers just wanting to find a name for the organism that is the focus of their studies. They often use keys written for areas well away from 
their study sites, like those in Fauvel (1923, 1927, Faune de France) and Day (1967, Polychaetes of Southern Africa). Day (1967) also provided well illustrated diagrammatic figures to all families and diagnostic characters which non specialists find helpful. Both these major references are almost 100 and 60 years old, respectively, and therefore do not reflect recent changes in classification, but are widely used as there are no other available sources in many parts of the world. Another problem is that typically, these researchers just list species found or used in their studies, without depositing voucher material (=reference material) in a recognised institution for examination and confirmation at a later date. Or sometimes they just repeat species lists from earlier studies. In doing so, probably little thought was given to where the species was originally described from, its habitat or depth. In part, this practice may have been due to the concept that polychaete species were widely distributed as many have long-lived larvae, and that the same species could occur from the intertidal to great depths. Indeed, this concept was part of the reason that Hartman $(1959,1965)$ synonymised so many species, without examining material or providing justifications.

Day \& Hutchings (1979) in their catalogue of polychaete species from Australia and New Zealand reported 17 genera and 32 species of terebellids from Australian waters (based entirely on the literature) and by 1991, Hutchings \& Glasby reported that this group was represented by 27 genera and 78 species of which 67 were only known from Australia after some extensive reviews of the terebellid fauna. They analysed the 11 species non endemic species, and two occurred in the Northern Hemisphere and the rest were Indo-Pacific species. Since that review, the two species from the Northern Hemisphere Amaeana trilobata (Sars, 1863) and Hauchiella tribullata (McIntosh, 1869) have not been found in Australian waters (Nogueira et al. 2015a, b) despite extensive collecting. This redescription of the Australian terebellid fauna reflected the virtual lack of polychaete taxonomists in Australia prior to 1970, when one was appointed to the Australian Museum $(\mathrm{PH})$. Prior to this the fauna was largely described by workers based in Europe who received material from expeditions which collected in Australian waters and this led to many European species being recorded by Augener, Fauvel, McIntosh (see Day \& Hutchings 1979, for references).

Recently, we had an opportunity to work with a Chinese taxonomist who translated for us some Chinese regional faunal studies which included extensive lists of species described from areas outside of China and yet were reported in Chinese waters with no comment. The presence of these species was then repeated in subsequent surveys of different areas of the coast (Meng et al. 1994, Wu 1962, Wu et al. 1980). Rarely was any comment made about these widely distributed species in these papers. Attempts to borrow vouchers deposited during these surveys revealed that none had ever been deposited even though all these studies involved Wu Boa Ling who was based at the Institute of Oceanology in Qingdao, which hosts the largest collection of marine organisms in China. So the validity of the names could not be checked and therefore the value of these surveys must be questioned. This practice is not limited to China, but we suspect is widespread in many countries where available taxonomic literature is limited. Benthic ecological studies and faunal lists reviewed by Hutchings as editor of Zootaxa and Marine Pollution Bulletin (PH, pers. comm.) from many countries often list species which were described from far away locations and may have restricted distributions and she questions these distributions.

\section{Case study of a supposedly cosmopolitan species}

In order to demonstrate the problems associated with misidentifying polychaetes and the consequences of this, we examine the case of the blood worm Marphysa sanguinea (Montagu, 1813). This species occurs in intertidal rock crevices in Devon, UK and is used by recreational fishers as bait (Cole et al. 2018). The original species description is very brief (see Fig. 1A) and poorly illustrated at least by today's standards, and no type specimen was deposited, which was typical of those times. The illustration clearly shows a species of Marphysa but few details of characters which we now know to be important in distinguishing between species are neither illustrated or given in the description. Despite this brief description and inadequate illustrations, this species has been reported from around the world, and has been widely regarded as a 'cosmopolitan' species. Hutchings \& Karageorgopoulos (2003) list that the species has been reported from USA (Hartman 1944; Reish 1963; Gathof 1984), Mexico (Rioja 1947, 1962), South Africa (Day 1967), Japan (Miura 1977) and Australia (Rullier 1965) for example. In most of these papers the name is just given with no description. Although, Day (1967) provides a description and information about chaetae and cites Fauvel (1923) in his references to this 

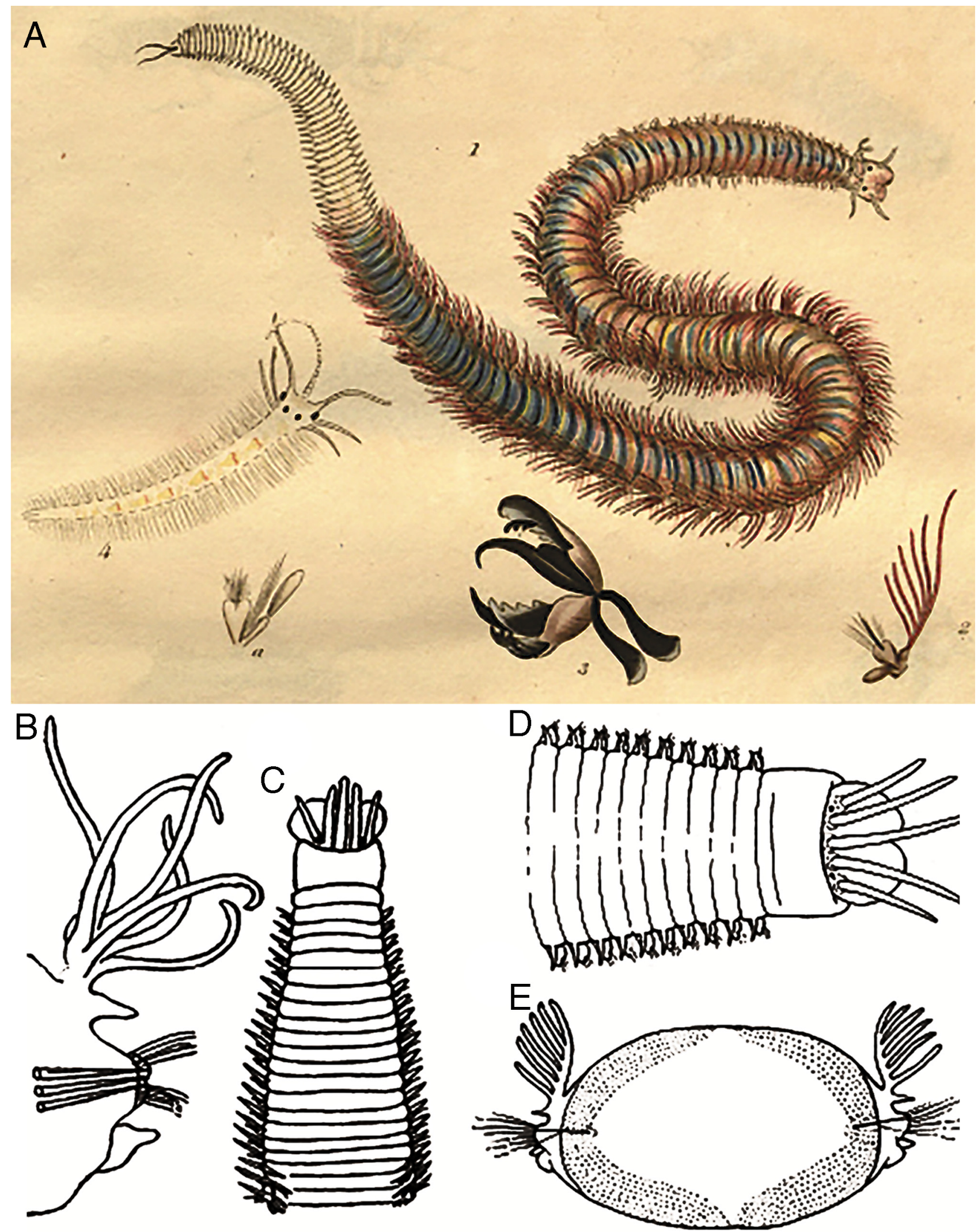

FIGURE 1. A. Original plate of Marphysa sanguinea (Montagu, 1813) illustrating entire worm (1), mid body parapodium (2), and dissected jaws (3). [the other images 4,5 belong to Myrianida pinnigera (Montagu, 1808, described as Nereis maculosa] B. Parapodium from mid body, C. Anterior view (B, C after Fauvel, 1923), D. Anterior view, E. Transverse section of mid segment (D, E after Day, 1967). 
species. The figures of Fauvel (Fig. 1B, C) differ from those shown in Day (1967) (Fig. 1D, E) and in neither case do the authors indicate which specimens were illustrated. Fauvel (1923) lists a wide distribution for this species including the English Channel, North and South Atlantic, Mediterranean, Indian Ocean, Red Sea and Australia, occurring in habitats such as sand, in Zostera beds or cracks in rocks. Day (1967) instead gives the distribution as the North Atlantic (Scotland), English Channel, Senegal to North Carolina, Gulf of Mexico, Mediterranean, New Zealand, Southern California and Japan as well as South West Africa, and habitats as muddy sandbanks and Zostera beds. Yet the type locality is rocky intertidal crevices. Neither of these authors actually list the material examined to prepare these descriptions which appear to be a generalised description of several species of Marphysa. We suggest that this generalised description of $M$. sanguinea is the reason why this name has been used to describe specimens found all around the world, suggesting it is a cosmopolitan species.

Anecdotal evidence suggested that this same species formed the basis of a commercial bait industry in Moreton Bay (Queensland, Australia), dug from intertidal mud flats with associated seagrass beds (Hopper 1994); however this seemed very unlikely to us given the very different habitat and environmental conditions. In order to resolve this situation, $M$. sanguinea from the type locality needed to be redescribed and a neotype designated (Hutchings \& Karageorgopoulos 2003). This then allowed the species in Moreton Bay to be described as a new species M. mullawa Hutchings \& Karageorgopoulos 2003. Subsequently, other species within the $M$. sanguinea complex have been described: M. elityeni from South Africa by Lewis \& Karageorgopoulos 2008; M. fauchaldi from northern Australia by Glasby and Hutchings 2010; M. kristiani and M. pseudosessiloa from New South Wales, Australia by Zanol et al. 2016, 2017; M. maxidenticulata, M. tripectinata, M. multipectinata, M. tribranchiata from China by Liu et al. 2017, 2018; M. moribidii from Malaysia by Idris et al. 2014; M. victori from France by Lavesque et al. 2017, M. iloiloensis from Philippines by Glasby et al. 2019 and M. gaditana and $M$. chirigota from Spain (Martin et al. 2020). Recently, fresh material was collected from close to the type locality of M. sanguinea for molecular work and is included in the recent study by Lavesque et al. (2019b) which shows that its distribution is limited to the English Channel and the Bay of Biscay. Certainly other undescribed species in this group of Marphysa occur (Hutchings et al. 2020) in the Indo-Pacific and they seem to be very habitat specific.

Based on the concerted efforts of the researchers noted above, it seems clear that Marphysa sanguinea is not a widely distributed "cosmopolitan" species, but rather comprises a suite of morphologically similar species. This conclusion is also supported by Molina-Acevedo \& Carrera-Parra (2015) who recently re-erected three species of Marphysa which had been synonymised with $M$. sanguinea from the Grand Caribbean as well as suggesting that all previous records of M. sanguinea from this region should be re-examined.

Not all specimens of M. sanguinea listed on GenBank even belong to the genus (Lavesque et al. 2019b) but in most of these studies it appears that no vouchers were deposited or any mention even made of the taxonomic problems within the complex. So while all species of the $M$. sanguinea complex superficially look alike, they may have very different life history traits (Cole et al. 2018), habitat requirements and of course genetic sequences. [Our reference to the M. sanguinea complex is based on Fauchald (1970) who split the large genus up into a series of groups, based on the type of chaetae and the proportion of body with branchiae]. As we are unaware of which species the studies listed by Lavesque et al. (2019b) actually refer to, these studies do not contribute to our knowledge of $M$. sanguinea, but only provide fragmentary information about many closely related species which is not helpful. The situation is even more complex as this group is widely harvested for bait worldwide. For example, China exports live worms from this species complex to several sites in south east Asia - but we do not know which species they actually export. The problem is exacerbated when fishers release live animals into the new habitats (Kilian et al. 2012) and exotic populations are established. Beyond doubt these exported bait worms consist of a mixture of species as material described by Liu et al. $(2017,2018)$ contained five new species all bought from a single bait collector.

Recent studies have also shown that more than one species of the genus can occur within a locality, each occurring in a particular habitat. Zanol et al. (2017) found that two species of this complex occurred on the same mud flat on the Hawkesbury River, NSW and could not be distinguished in the field. This mud flat has muddy sand interspersed with seagrass, and seems likely that the two species occurred either in the muddy sand or the seagrass which was often collected in the same sample. A Queensland marine worm identification guide on the website of Queensland Department of Agriculture and Fisheries (https://www.daf.qld.gov.au/ 
business-priorities/fisheries/recreational/marine-worm) also shows that at least three species of this complex occur in Moreton Bay, Queensland, only one of which is described; the other two will shortly be described (Glasby pers. comm.). More recently, a species of Marphysa from Japan has been recorded in Arcachon Bay; it is likely to have been introduced with oysters prior to 1970, probably as egg capsules attached to the live oysters and until recently undetected and wrongly identified as M. sanguinea. Marphysa victori Lavesque, Daffe, Bonifacio \& Hutchings, 2017 (synonymised with M. bulla Liu, Hutchings \& Kupriyanova, 2018) also occurs in China, so it is unclear whether it was translocated from China to Japan by imports of bait worms and then accidently transported to France (Lavesque et al. 2020b) via imports of live oysters.

While we have focused on Marphysa sanguinea, there are plenty of other polychaete examples which have similar problems, such as Thelepus setosus (Quatrefages, 1866), Capitella capitata (Fabricius, 1780), Pista cristata (Müller, 1776), and Owenia fusiformis Delle Chiaje, 1844. But there are some polychaete species which do appear to be "true" cosmopolitan species such as Proscoloplos cygnochaetus Day, 1954, as shown by Meyer et al. (2008). Another example of "true" cosmopolitan species is Sclerolinum contortum Smirnov, 2000, which Georgieva et al. (2015) showed to be a bipolar cosmopolitan species. Zhou et al. (2020) also showed that there is trans-oceanic dispersal of Osedax rubiplumus Rouse, Goffredi \& Vrijenhoek 2004, through the Southern Ocean.

The presence of supposedly widely distributed or cosmopolitan species has also been reported among many other taxonomic groups such as sponges (Klautau et al. 1999), sea anemones (Monteiro et al. 1997), bryozoans (Harmelin et al. 2012), crustaceans (Plagge et al. 2016) and is also present among meiofaunal groups (Van Steenkiste et al. 2018). This may have led to problems in distinguishing between native and introduced species.

\section{A way forward}

So, how can this situation be improved to ensure that users of taxonomic information are using the most up to date information? This is essential to ensure that scientific data are actually useful, and contribute to increasing our knowledge of species and their role in marine ecosystems. For example, in the case of identifying nonnative species, failure to accurately identify the species may lead to costly consequences (Hutchings 2018). For many polychaetes only one or so species within a genus is invasive (Sun et al. 2015; Lavesque et al. 2020 $a, b)$ so it is critical to distinguish between native and non-native species in the genus.

It is going to require a variety of actions by all of us and these are discussed below without necessarily any ranking.

It is going to be up to us taxonomists when reviewing ecological papers to highlight potential problems with using names of species described from distant localities and hope that editors will take notice of this. But, we taxonomists are also part of the problem too, in just repeating previous lists of synonymies without careful checking. As Hutchings \& Kupriyanova (2018) suggested, all species should be regarded as having restricted distributions unless otherwise proven; such as species introduced by aquaculture, ballast water and hull fouling for example. Also, as mentioned above there are some examples of "true" cosmopolitan species confirmed by both molecular and morphological studies (Meyer et al. 20008; Georgieva et al. 2015 and Zhou et al. 2020).

Improved communication between taxonomists and ecologists is critical to improving the accuracy of identification (Bortolus 2008). Ecologists and other researchers should be encouraged to deposit vouchers at a museum or other recognised/registered institution, although this must be done in conjunction with museum collection managers to ensure that such material is adequately labelled with all the necessary information (e.g. exact location of samples, date, habitat, name of collector and where required details regarding the necessary permit numbers). But even this may be challenging given the space and staffing limitations of some museums. In cases where space is limited the researchers should liaise with taxonomists and collection managers and discuss the importance of lodging material. For example has the material been collected from an area previously poorly sampled? Or from a group which is known to include invasive species? Certainly some institutions are unwilling to accept vouchers given their lack of funding. In Australia, voucher collections from the region are accepted especially if the samples result from collaboration with museum taxonomists to confirm the identifications. Also permits may require material to be lodged in the relevant state or national museum, certainly this is true in Australia. 
This lack of resources in many natural history museums was recently highlighted by Bakker et al. (2020) and they provide a good synthesis of the value of their collections and stress the need for scientists, citizens and policy makers to give them the proper recognition and ensure those collections are maintained and enhanced. If this also resulted in additional funding then it would be easier for collections to be updated. At the Australian Museum, a substantial government grant recently awarded is enabling collections to be digitised, which in part is a recognition of the value of these collections and to improve their use ( $\mathrm{PH}$, pers. comm.).

The value of vouchers was highlighted by a benthic survey of Port Phillip Bay, Victoria, Australia, which compared the fauna collected in 1995/1996 with those collected in the early 1970's and lodged in the Museum of Victoria. This allowed the documentation of newly introduced non-indigenous species from ballast water and hull fouling as well as correction of some identifications from the earlier survey (Hewitt et al. 2004).

Another action would be for journal editors and reviewers to request that researchers provide details of the literature they used to identify their animals, or the specialists they used to help them identifying their fauna. This could be in the form of a "taxonomy best practices checklist" that is on the journal website, which could include checking to see if there have been revisions to the taxonomy of the group they are working with (e.g., as noted in WoRMS).

While this would be helpful in ecological studies, it almost certainly would not be followed by researchers working on physiology or reproductive studies. For instance one of us $(\mathrm{PH})$ examined a $\mathrm{PhD}$ on the reproductive biology of two species of nereidids and the results were confusing. When asked if vouchers had been deposited, the supervisor said no but volunteered to collect samples which were then examined and found to contain two different species in two different genera, making the students' results meaningless.

\section{Actions for taxonomists}

Taxonomists need to produce better illustrated keys to make it easier for non-specialists to identify their fauna and advertise our willingness to help ecologists and other biologists in checking their identifications. The present taxonomists must mentor the next generation of taxonomists and try to reverse the decline in taxonomic expertise which seems to be occurring everywhere (Hutchings 2020). Taxonomists must be willing to run identification courses especially in locations where the fauna is poorly known and to host students in their labs. Taxonomists when preparing taxonomic papers must carefully check synonymies and not just repeat previously published ones, and hopefully the specialist editors of taxonomic journals will also check them. The World Register of Marine Species (http://www.marinespecies.org) makes this task easier than previously, although we have found some mistakes do occur. Fortunately, these can be rectified easily by contacting the different editors and website staff. Reviewers of these papers should also be alerted to these potential problems. The value of WoRMS and how it is continually update needs to be more widely circulated throughout the scientific community.

In Australia, all the natural history museums regularly provide updates of their digitized collections to the Atlas of Living Australia (ala.org.au) and this allows anybody to query the distribution of a species based on museum records for free. It also includes biodiversity research data from universities and research organisations and survey data from government departments. This data is made available to international databases.

When we review ecological papers, we must comment on the validity of the identifications, and ask who identified the fauna, and hopefully the editors will consider these comments and ensure that authors provide this information either in the paper or at least in the acknowledgements. We must also be willing to give papers at conferences to spread the word to ecologists and other researchers that correct identification is actually very important, but we also need to be willing to work with non-taxonomists to help them identify their fauna. We must also encourage editors to only accept papers where voucher material is associated with sequence data deposited in Genbank. In the ideal world, GenBank would change its rules only to accept sequences if associated with vouchers. Certainly in our research when looking for sequences we only use those from labs where we trust the identifications as done by the relevant experts of that group.

We recognize that making these changes is going to be difficult, but this does not mean that we should not try to make them. We taxonomists need to be far more engaged in the scientific community, which we know is going to be difficult given the trend towards decreasing funding for taxonomic research (Hutchings 
2019). So, we really have to better communicate the consequences of failing to correctly identify species and the importance of a species name and even use this as a leverage to increase funding for taxonomy. A good summary of the reasons for correctly identifying species is given in the Discovering Biodiversity (2018) plan that was recently launched in Australia (https://www.science.org.au/files/userfiles/support/reports-andplans/2018/taxonomy-decadal-plan-hi-res-v200618.pdf) and now the task is to obtain the funding to actually implement it and this is work in progress. We suggest that the issues highlighted in this Plan are relevant to all other parts of the world.

Examples of taxonomic workshops occur in Europe, with taxonomic experts giving both theoretical and practical courses on a group or family. In UK, benthic invertebrate taxonomic workshops are organised in the frame of the NE Atlantic Marine Biological Analytical Quality Control Scheme (NMBAQCS). In France, since 2010, RESOMAR (French marine stations and observatories network) organises each year a one weekcourse focused on a specific family with presence of one or two international experts.

Finally as we taxonomists seek better interaction with the rest of the scientific community, we need to develop resources and tools to facilitate the identification of the biota. We know that sorting and identifying benthic fauna is time consuming and benthic ecologists and consultants typically have strict time tables and budgets to complete the identifications and so they refer only to the available literature. So we must make it easier for them by the development of free online interactive keys, well- illustrated field guides, and digitization of museum collections which makes it easier to check species distributions. A current project is underway to provide a key to all groups of marine annelids and species guides to some families ( $\mathrm{PH}$, pers. com.). Similar projects should be developed for other groups of terrestrial and aquatic invertebrates, as the problems highlighted for polychaetes are not unique. As well we must be willing to work with ecologists and be involved in planning expeditions to ensure sufficient funding is available for sorting, writing up the data and incorporating voucher material into museum collections.

Given the urgent need for better communication and cooperation among taxonomists and other biologists, another very important issue is to ensure that taxonomy is actually taught at Universities. It is critical that those continuing on to become ecologists, physiologists, managers, molecular biologists etc. actually understand the role of taxonomy and how it underpins all aspects of biology (Hutchings 2020).

\section{Acknowledgments}

Authors would like to thank Guillaume Bernard (EPOC Arcachon) and Gabin Droual (Ifremer Brest) for sharing their interesting points of view. NL has received financial support from the French State in the frame of the "Investments for the future" Programme IdEx Bordeaux, reference ANR-10-IDEX-03-02. We should also like to thank Chris Glasby for critically reading the manuscript, and also Sara Lindsay and Greg Rouse for providing constructive comment and editing the figure.

\section{References}

Bakker, F.T., Antonelli, A., Clarke, J.A., Cook, J.A., Edwards, S.V., Ericson, P.G.P., Faurby, S., Ferrand, N., Gelang, M., Gillespie, R.G., Irestedt, M., Lundin, K., Larsson, E., Matos-Maraví, P., Müller, J, von Proschwitz, T., Roderick, G.K., Schliep, A., Wahlberg, N., Wiedenhoeft, J. \& Källersjö, M. (2020) The Global Museum: natural history collections and the future of evolutionary science and public education. PeerJ, 8, e8225 . https://doi.org/10.7717/peerj.8225

Blake, J.A. (2009) Redescription of Capitella capitata (Fabricius) from West Greenland and designation of a neotype (Polychaeta, Capitellidae). Zoosymposia, 2, 55-80.

https://doi.org/10.11646/zoosymposia.2.1.7

Blake, J.A. (2015) New species of Chaetozone and Tharyx (Polychaeta: Cirratulidae) from the Alaskan and Canadian Arctic and the Northeastern Pacific, including a description of the lectotype of Chaetozone setosa Malmgren from Spitsbergen in the Norwegian Arctic. Zootaxa, 3919 (3), 501-552.

https://doi.org/10.11646/zootaxa.3919.3.5

Blake, J.A. (2019) New species of Cirratulidae (Annelida, Polychaeta) from abyssal depths of the Clarion-Clipperton Fracture Zone, North Equatorial Pacific Ocean. Zootaxa, 4629 (2), 151-187.

https://doi.org/10.11646/zootaxa.4629.2.1 
Bonifácio, P. \& Menot, L. (2019) New genera and species from the Equatorial Pacific provide phylogenetic insights into deepsea Polynoidae (Annelida). Zoological Journal of the Linnean Society, 185 (3), 555-635.

https://doi.org/10.1093/zoolinnean/zly063

Bortolus, A. (2008) Error Cascades in the Biological Sciences: The Unwanted Consequences of Using Bad Taxonomy in Ecology. Ambio, 37 (2), 114-118. https://doi.org/10.1579/0044-7447(2008)37[114:ECITBS]2.0.CO;2

Caullery, M. (1944) Polychètes sédentaires de I'Expedition du Siboga: Ariciidae, Spionidae, Chaetopteridae, Chloraemidae, Opheliidae, Oweniidae, Sabellariida Sternaspidae, Amphictenidae, Ampharetidae, Terebellidae. Siboga Expedition Leiden, 24 (2), 1-204.

Cole, V.J., Chick, R.C. \& Hutchings, P.A. (2018) A review of global fisheries for polychaete worms as a resource for recreational fishers: diversity, sustainability and research needs. Review Fish Biology and Fisheries, 28, 543-565. https://doi.org/10.1007/s11160-018-9523-4

Discovering Biodiversity (2018) A Decadal plan for taxonomy and biosystematics in Australia and New Zealand 2018-2027. [https://www.science.org.au/files/userfiles/support/reports-and-plans/2018/taxonomy-decadal-plan-hi-res-v200618.pdf]

Day, J.H. (1954) The Polychaeta of Tristan da Cunha. Results of the Norwegian Scientific Expedition to Tristan da Cunha 19371938. 29, 1-35. page(s): 21, fig. 3a-f.

Day, J.H. (1967) A Monograph on the Polychaeta of Southern Africa. Part I. Errantia. British Museum (Natural History), London, 458 pp.

https://doi.org/10.5962/bhl.title.8596

Day, J.H. \& Hutchings, P.A. (1979) An Annotated Checklist of Australian and New Zealand Polychaeta and Myzostomidae. Records of the Australian Museum, 3, 80-161. https://doi.org/10.3853/j.0067-1975.32.1979.203

Delle Chiaje, S. (1844) Descrizione e Notomia degli Animali Invertebrati della Sicilia Citeriore osservati vivi negli anni 1822 1830. Tomo Ottavo. Appendice, Osservazioni Critiche, Indice Generale. Stabilamento Tipografico di C. Batelli e Comp., Napoli, 48 pp.

Ehlers, E. (1864-1868) Die Borstenwürmer (Annelida Chaetopoda) nach systematischen und anatomischen Untersuchungen dargestellt. Wilhelm Engelmann, Leipzig, Vol. 1 (1864), pp. 1-268; Vol. 2 (1868), pp. 269-748.

Ehlers, E. (1887) Reports on the results of dredging, under the direction of L.F. Pourtales, during the years 1868-1870, and of Alexander Agassiz, in the Gulf of Mexico (1877-78), and in the Caribbean Sea (1878-79), in the U.S. Coast Survey Steamer "Blake", Lieut.-Com. C.D. Sigsbee, U.S.N., and Commander J.R. Bartlett, U.S.N., commanding. 31. Report on the annelids. Memoirs of the Museum of Comparative Zoology at Harvard College, 15, 1-335. https://doi.org/10.5962/bhl.title.65639

Ehlers, E. (1904) Neuseeländische Anneliden. Abhandlungen der Königlichen Gesellschaft der Wissenschaften zu Göttingen. Mathematisch-Physikalische Klasse. Neue Folge, 3, 1-80.

Ehlers, E. (1913) Die Polychaeten-Sammlungen der deutschen Südpolar-Expedition 1901-1903. Deutsche Südpolar-Expedition, 13, 397-598.

Fabricius, O. (1780) Fauna Groenlandica. Hafniae et Lipsiae, xiv + 452 pp.

Fauchald, K. (1970) Polychaetous annelids of the families Eunicidae, Lumbrineridae, Iphitimidae, Arabellidae, Lysaretidae and Dorvilleidae from western Mexico. Allan Hancock Monograph in Marine Biology, 5, 1-335.

Fauvel, P. (1923) Polychètes Errantes. Faune de France, Paris 5, 1-488.

Fauvel, P. (1927) Polychètes Sédentaires. Addenda aux Errantes, Archiannélides, Myzostomaires. Faune de France 16. Lechevalier, Paris, 494 pp.

Gathof, J.M. (1984) Family Eunicidae Savigny, 1818. In: Uebelacker, J.M. \& Johnson, P.G. (Eds.), Atlas of the Polychaetes of the Northern Gulf of Mexico. Barry A. Vittor \& Ass. 7, Chapter 40, 1-31.

Georgieva, M.N., Wiklund, H., Bell, J.B., Eilertsen, M.H., Mills, R.A., Little, C.T.S. \& Glover, A.G. (2015) A chemosynthetic weed: the tubeworm Sclerolinum contortum is a bipolar, cosmopolitan species. Bmc Evolutionary Biology, $2015,15$. https://doi.org/10.1186/s12862-015-0559-y

Glasby, C.J. \& Hutchings, P.A. (2010) A new species of Marphysa Quatrefages, 1865 (Polychaeta: Eunicida: Eunicidae) from northern Australia and a review of similar forms from the tropical Indo-west Pacific. Zootaxa, 2352, $29-52$. https://doi.org/10.11646/zootaxa.2352.1.2

Glasby, C.J., Mandario, M.A., Burghardt, I., Kupriyanova, E., Gunton, L.M. \& Hutchings, P.A. (2019) A new species of the Marphysa sanguinea Quatrefages, 1865 species complex (Annelida: Eunicida: Eunicidae) from the Philippines, and a key to members of the complex in Southeast Asia. Zootaxa, 4674 (2), 264-282.

https://doi.org/10.11646/zootaxa.4674.2.7

Glover, A.G., Dahlgren, D.G., Wiklund, H., Mohrbeck, I. \& Smith, C.R. (2016) An End-End DNA Taxonomy Methodology for Benthic Biodiversity Survey in the Clarion-Clipperton Zone, Central Pacific Abyss. Journal of Marine Science and Engineering, 4 (2), 1-34. https://doi.org/10.3390/jmse4010002

Goffredi, S.K., Johnson, S., Tunnicliffe, V., Caress, D., Clague, D., Escobar, E., Lundsten, L., Paduan, J.B., Rouse, G., Salcedo, D.L., Soto, L.A., Spelz-Madero, R., Zierenberg, R. \& Vrijenhoek, R. (2017) Hydrothermal vent fields discovered in the southern Gulf of California clarify role of habitat in augmenting regional diversity. Proceedings of the Royal Society B- 
Biological Sciences, 284. Artn 20170817

https://doi.org/10.1098/rspb.2017.0817

Grassle, J.F. \& Maciolek, N.J. (1992) Deep-sea species richness: regional and local diversity estimates from quantitative samples. American Naturalist, 139, 313-341.

https://doi.org/10.1086/285329

Gunton, L.M., Kupriyanova, E. Alvestad, T., Avery, L., Blake, J.A., Biriukova, O., Böggemann, M., Borisova, P., Budaeva N., Burghardt I., Capa, M., Georgieva, M.N., Glasby, C.J., Hsueh, P. -W., Hutchings, P., Jimi,N., Konsgrud, J.A., Langeneck, J., Meißner, K., Murray, A., Nikolic, M., Paxton, H., Ramos, D., Schulze, A., Sobczyk, R., Watson, C., Wiklund, H., Wilson, R., Zhadan. A. \& Zhang. J. (In review) Annelids of the eastern Australian abyss collected by the 2017 RV Investigator voyage. Zookeys.

Harmelin, J.-G., Vieira, L.M., Ostrovsky, A.N., Cáceres-Chamizo, J.P. \& Sanner, J. (2012) Scorpiodinipora costulata (Canu \& Bassler, 1929) (Bryozoa, Cheilostomata), a taxonomic and biogeographic dilemma: complex of cryptic species or humanmediated cosmopolitan colonizer? Zoosystema, 34, 123-138.

https://doi.org/10.5252/z2012n1a5

Hartman, O. (1944) Polychaetous annelids. Part V. Eunicea. Allan Hancock Pacific Expedition, 10, 1-239.

Hartman, O. (1959, 1965) Catalogue of the Polychaetous Annelids of the World. Parts 1 and 2. Allan Hancock Foundation Occasional Paper, 23, 1-628. Supplement and index (1965) 197 pp.

Hewitt, C.L., Campbell, M.L., Thresher, R.E., Martin, R.B., Boyd, S., Cohen, B.F., Currie, D.R., Gomon, M.F., Keough, M.J., Lewis, J.A., Lockett, M.M., Mays, N., McArthur, M.A., O’Hara, T.D., Poore, G.C.B., Ross, D.J., Storey, M.J., Watson, J.E. \& Wilson, R.S. (2004) Introduced and cryptogenic species in Port Phillip Bay, Victoria Australia. Marine Biology, 144, 183-202. https://doi.org/10.1007/s00227-003-1173-x

Hopper, G.A. (1994) The reproductive ecology and biology of Marphysa sanguinea (Annelida: Polychaeta), a fisheries resource. Honours Thesis, Dept. of Zoology, University of Queensland, Australia.

Hutchings, P. (1998) Biodiversity and functioning of polychaetes in benthic sediments. Biodiversity and Conservation, 7, 11331145. https://doi.org/10.1023/A:1008871430178

Hutchings, P. (2018) Marine introduced species in Australia, where to from here? A personal perspective from a practising taxonomist. Marine Pollution Bulletin, 136, 447-480. https://doi.org/10.1016/j.marpolbul.2018.09.047

Hutchings, P., Lavesque, N., Priscilla, L., Daffe, G., Malathi, E. \& Glasby, C.J. (2020) A new species of Marphysa (Annelida : Eunicidae) from India, with notes on previously described or reported species from the region. Zootaxa, 4852 (3), 285 308.

https://doi.org/10.11646/xootaxa.4852.3.2

Hutchings, P. (2019) An advocate for taxonomic research in Australia. Pacific Conservation, 25 (1), 34-36. https://doi.org/10.1071/PC17033

Hutchings, P. (2020) Major issues facing taxonomy- a personal perspective. Megataxa, 1 (1), 46-48. https://doi.org/10.11646/megataxa.1.1.9

Hutchings, P.A. \& Glasby, C.J. (1991) Phylogenetic Implications of the Biogeography of Australian Terebellidae. Ophelia, Supplement, 5, 565-572.

Hutchings, P.A. \& Karageorgopoulos, P. (2003) Designation of a neotype of Marphysa sanguinea (Montagu, 1813) and a description of a new species of Marphysa from eastern Australia. Hydrobiologia, 496, 87-94. https://doi.org/10.1023/A:1026124310552

Hutchings, P.A. \& Kupriyanova, E. (2018) Cosmopolitan species, fact or fashion? A personal perspective. Invertebrate Systematics, 32, 1-9. https://doi.org/10.1071/IS17035

Idris, I., Hutchings, P.A. \& Arshad, A. (2014) Description of a new species of Marphysa Quatrefages, 1865 (Polychaeta: Eunicidae) from the west coast of Peninsular Malaysia and comparisons with species from Marphysa group A from the Indo-West Pacific and Indian Ocean. Memoirs of Museum of Victoria, 71, 109-121. https://doi.org/10.24199/j.mmv.2014.71.11

Kilian J.V., Klauda, R.J., Widman, S., Kashiwagi, M., Bourquin, R., Weglein, S. \& Schuster, J. (2012) An assessment of a bait industry and angler behavior as a vector of invasive species. Biological Invasions, 14, 1469-1481. https://doi.org/10.1007/s10530-012-0173-5

Klautau, M., Russo, C.A.M., Lazoski, C., Boury-Esnault, N., Thorpe, J.P., \& Sole-Cava, A.M. (1999) Does cosmopolitanism result from overconservative systematics? A cases study using the marine sponge Chondrilla nucula. Evolution, 53, 14141422 . https://doi.org/10.1111/j.1558-5646.1999.tb05406.x

Langeneck, J., Busoni, G., Aliani, S., Lardicci, C. \& Castelli, A. (2019) Distribution and diversity of polychaetes along a bathyal escarpment in the western Mediterranean Sea. Deep Sea Research Part 1. Oceanographic Research Papers, 144, 85-94. https://doi.org/10.1016/j.dsr.2019.01.006

Lavesque, N., Daffe, G., Bonifácio, P. \& Hutchings, P. (2017) Marphysa victori sp. nov. (Annelida, Eunicidae), a new species 
of the Sanguinea group from French waters (Bay of Biscay, NE Atlantic). Zookeys, 716, 1-17.

https://doi.org/10.3897/zookeys.716.14070

Lavesque, N., Hutchings, P., Daffe G., Nygren, A. \& Londono-Mesa, M. (2019a) A revision of the French Trichobranchidae (Polychaeta), with descriptions of nine new species. Zootaxa, 4664 (2), 151-190. https://doi.org/10.11646/zootaxa.4664.2.1

Lavesque, N., Daffe, G., Grall, J., Zanol, J., Gouillieux, B. \& Hutchings, P. (2019b) Guess who? On the importance of using appropriate name: case study of Marphysa sanguinea (Montagu, 1813). Zookeys, 859, 1-15. https://doi.org/10.3897/zookeys.859.34117

Lavesque, N., Londoño-Mesa, M.H., Daffe, G., Hutchings, P. (2020a). A revision of the French Telothelepodidae and Thelepodidae (Annelida, Terebelliformia), with descriptions of three species and first European record of a non-indigenous species. Zootaxa, 4810(2), 305-327. https://doi.org/10.11646/zootaxa.4810.2.4

Lavesque, N., Hutchings, P., Abe, H., Daffe, G., Gunton, L.M. \& Glasby C.J. (2020b) Confirmation of the exotic status of Marphysa victori Lavesque, Daffe, Bonifácio \& Hutchings, 2017 (Annelida) in French waters and synonymy of Marphysa bulla Liu, Hutchings \& Kupriyanova, 2018. Aquatic Invasions. https://doi.org/10.3391/ai.2020.15.3.01

Lavesque, N., Hutchings, P., Daffe, G. \& Londoño-Mesa, M.H. (2020c) Revision of the French Polycirridae (Annelida, Terebelliformia), with descriptions of eight new species. Zootaxa, 4869 (2), 151-186. https://doi.org/10.11646/zootaxa.4869.2.1

Lewis, C. \& Karageorgopoulos, P. (2008) A new species of Marphysa (Eunicidae) from the western Cape of South Africa. Journal of the Marine Biological Association of the United Kingdom, 88 (2), 277-287. https://doi.org/10.1017/S002531540800009X

Liu, Y., Hutchings, P., \& Sun, S. (2017) Three new species of Marphysa Quatrefages, 1865 (Polychaeta: Eunicida: Eunicidae) from southeast-southern China and redescription of Marphysa sinensis Monro. Zootaxa, 4263 (2), 228-250. https://doi.org/10.11646/zootaxa.4377.2.3

Liu Y., Kupriyanova, E. \& Hutchings, P. (2018) Two new species of Marphysa Quatrefages, 1865 (Polychaeta: Eunicida: Eunicidae from northern coast of China and redescription for Marphysa orientalis Treadwell, 1936. Zootaxa, 4377 (2), $191-215$. https://doi.org/10.11646/Zootaxa.4377.2.3

Martin, D., Gill, J., Zanol, J., Mecca, M.A, \& Perez Portela, R. (2020) Digging the diversity of Iberian bait worms Marphysa (Annelida, Eunicidae). PLoS ONE, 15 (1), e0226749. https://doi.org/10.1371/journal.pone.0226749

McIntosh, W.C. (1869) On the structure of the British nemerteans, and some new British annelids. Transactions of the Royal Society of Edinburgh. 25 (2), 305-433, plates IV-XVI. https://doi.org/10.1017/S0080456800035262

McIntosh, W.C. (1885) Report on the Scientific Results of the Voyage of H.M.S. Challenger during the Years $1873-1876$ under the command of the Captain George S. Nares, R.N., F.R.S. and the Late Captain Frank Tourle Thomson, R.N. Zoology, 12, $1-554$.

Meng, F., Hong, X. \& Wu, B. (1994) Studies on Polychaeta of Hainan Island Waters II. Journal of Oceanography of Huanghai \& Bohai Seas, 12 (1), 35-51. [in Chinese]

Menot, L., Sibuet, M., Carney, R.S., Levin, L.A., Rowe, G.T., Billet, D.S.M. \& Krylova, E. (2010) New perceptions of continental margin biodiversity. In: McIntyre, A D. (Ed.), Life in the World's Oceans. Oxford: Blackwell Publishing Ltd, pp, 79-102. https://doi.org/10.1002/9781444325508.ch5

Meyer, A., Bleidorn, C., Rouse, G.W. \& Hausen, H. (2008) Morphological and molecular data suggest a cosmopolitan distribution of the polychaete Proscoloplos cygnochaetus Day, 1954 (Annelida, Orbiniidae). Marine Biology, 153 (5), 879-889. https://doi.org/10.1007/s00227-007-0860-4

Miura, T. (1977) Eunicid polychaetous annelids from Japan. 11 La mer. Bulletin de la Société. franco-japonaise d'océanographie $15,61-81$.

Molina-Acevedo, I.C. \& Carrera-Parra, L.F. (2015) Reinstatement of three species of the Marphysa sanguinea complex (Polychaeta: Eunicidae) from the Grand Caribbean Region. Zootaxa, 3925 (1), 37-55. https://doi.org/10.11646/zootaxa.3925.1.3

Montagu, G. (1813) Descriptions of several new or rare animals, principally marine, found on the south coast of Devonshire. Transactions of the Linnean Society of London, 11, 18-21. https://doi.org/10.1111/j.1096-3642.1813.tb00035.x

Monteiro, F.A., Sole-Cava A.M. \& Thorpe P. (1997) Extensive genetic divergence between populations of the common intertidal sea anemone Actinia equina from Britain, the Mediterranean and the Cape Verde Islands. Marine Biology, 129, 425-433. https://doi.org/10.1007/s002270050183

Müller, O.F. (1776) Zoologiae Danicae prodromus: seu Animalium Daniae et Norvegiae indigenarum characteres, nomina, et synonyma imprimis popularium. Hafniae, Typiis Hallageriis, $274 \mathrm{pp}$. https://doi.org/10.5962/bhl.title.13268

Nogueira, J.M.M., Hutchings, P. \& Carrerette, O. (2015a) Polycirridae (Annelida, Terebelliformia) from Lizard Island Group, 
Great Barrier Reef, Australia. Zootaxa, 4019 (1), 437-483.

https://doi.org/10.11646/zootaxa.4019.1.17

Nogueira, J.M.M., Carrerette, O. \& Hutchings, P. (2015b) Review of Amaeana Hartman, 1959 (Annelida, Terebelliformia, Polycirridae) with descriptions of six new species. Zootaxa, 3994 (1), 001-052. https://doi.org/10.11646/zootaxa.3994.1.1

Nygren, A., Parapar, J., Pons, J., Meißner, K., Bakken, T., Kongsrud, J.A., Oug, E., Gaeva, D., Sikorski, A., Johansen, R.A., Hutchings, P., Lavesque, N. \& Capa, M. (2018) A megacryptic species complex hidden among one of the most common annelids in the North East Atlantic. PLoS ONE, 13 (6), e0198356. https://doi.org/10.1371/journal.pone.0198356

Parapar, J. \& Hutchings, P. (2014) Redescription of Terebellides stroemii (Polychaeta, Trichobranchidae) and designation of a neotype. Journal of the Marine Biological Association of the UK, 95 (2), 323-337. https://doi.org/10.1017/S0025315414000903

Pamungkas, J., Glasby, C.J., Read, G.B., Wilson, S.P. \& Costello M.J. (2019) Progress and perspectives in the discovery of polychaete worms (Annelida) of the world. Helgoland Marine Research, 73, 4. https://doi.org/10.1186/s10152-019-0524-z

Plagge, C., Nguyen, T.S., Peter, L. K. Ng., Türkay, M., Streit, B. \& Klaus, S. (2016) Liocarcinus corrugatus (Pennant, 1777) (Crustacea: Brachyura: Portunidae): a cosmopolitan brachyuran species? Raffles Bulletin of Zoology, 64, 374-388.

Quatrefages, A. (1866) Histoire naturelle des Annelés marins et d'eau douce. Annélides et Géphyriens. Tome second. Librairie Encyclopédique de Rôret, Paris, 337-794. https://doi.org/10.5962/bhl.title.122818

Queensland Department of Agriculture and Fisheries (2017) A Queensland marine worm identification guide. Available from: https://www.daf.qld.gov.au/business-priorities/fisheries/recreational/marine-worm (accessed 1 March 2020)

Ranzani, C. (1817) Descrizione di una nuova specie del genere Thalassema. Opuscoli Scientifici, Bologna, 1, 112-116, Plate 4.

Reish, D.J. (1963) A quantitative study of the benthic polychaetous annelids of Bahia de San Quinton, Baja California. Pacific Naturalist, 3, 399-436.

Rioja, E. (1947) Estudios anelidologicos XV111. Observaciones y datossobre algunos anelidos poliquetos des Golfo de California y costas de Baja California. Anales del Instituto de Biología la Universidad Nacional Mexico, 18, 517-526.

Rioja, E. (1962) Estudios anelidologicos XXV1. Algunos anelidos poliquetos de las costas del Pacifico de Mexico. Anales del Instituto de Biología la Universidad Nacional Mexico, 33, 131-229.

Rouse, G.W., Goffredi, S.K. \& Vrijenhoek, R.C. (2004) Osedax: bone eating marine worms with dwarf males. Science, 305, $668-671$. https://doi.org/10.1126/science. 1098650

Rullier, F. (1965) Contribution à la faune des annélides polychètes de l'Australie. University of Queensland Papers. Department of Zoology, 2, 163-2010.

Sars, M. (1835) Beskrivelser og Iagttagelser over nogle maerkelige eller nye i Havet ved den Bergenske Kyst Levende Dyr af Polypernes, Acalephernes, Radiaternes, Annelidernes og Molluskernes classer, med en kort Oversigt over de hidtil af Forfatteren sammesteds fundne Arter og deres Forekommen. T. Hallager, Bergen, 81 pp. https://doi.org/10.5962/bhl.title.13017

Schmarda, L.K. (1861) Neue Wirbellose Thiere: Beobachted und Gesammelt auf einer Reise um die Erdr 1853 bis 1857. Turbellarien, Rotatorien und Anneliden. Leipzig, Verlag von Wilhelm Engelmann. Erster Band, Zweite Hälfte. [http:// www.biodiversitylibrary.org/ia/neuewirbelloseth21861schm]

Smirnov, R.V. (2000) Two new species of Pogonophora from the arctic mud volcano off northwestern Norway. Sarsia, 85,141150. https://doi.org/10.1080/00364827.2000.10414563

Sun, Y., Wong, E., ten Hove, H.A., Hutchings, P.A., Williamson, J.E. \& Kupriyanova, E.K. (2015) Hydroides (Serpulidae, Annelida) from Australia. Zootaxa, 4009 (1), 1-99. https://doi.org/10.11646/zootaxa.4009.1.1

Thompson, C.F. \& Pape, T. (2016) Sherborn's influence on Systema Dipterorum. In: Michel, E. (Ed.), ZooKeys, 550, $135-152$. https://doi.org/10.3897/zookeys.550.9447

Van Steenkiste, N.W.L., Herbert, E.R. \& Leander, B.S. (2018) Species diversity in the marine microturbellarian Astrotorhynchus bifidus sensu lato (Platyhelminthes: Rhabdocoela) from the Northeast Pacific Ocean. Molecular Phylogenetics and Evolution, 120, 259-273.

https://doi.org/10.1016/j.ympev.2017.12.012

Wu, B. (1962) The characteristics of polychaeta fauna in Fujian coast. Oceanologia et Limnologia Sinica, 4 (2), 87-96. [in Chinese]

Wu, B., Sun, R. \& Chen, M. (1980) Zoogeographical studies on polychaeta from the Xisha Island and its adjacent waters. Acta Oceanologica Sinica, 2 (1), 111-130. [in Chinese]

Zanol, J., Silva, T. \& Hutchings, P. (2016) Marphysa (Eunicidae, polychaete, Annelida) species of the Sanguinea-group from Australia, with comments on pseudo-cryptic species. Invertebrate Biology, 135 (4), 328-344. https://doi.org/10.1111/ivb.12146 
Zanol, J., Silva, T. \& Hutchings, P. (2017) One new species and two redescriptions of Marphysa (Eunicidae, polychaete, Annelida) species of the Aenea-group from Australia. Zootaxa, 4268 (3), 411-426.

https://doi.org/10.11646/zootaxa.4268.3.6

Zhang, J., Hutchings, P., \& Kupriyanova E. (2019) A revision of the genus Petta (Polychaeta Pectinariidae), with two new species from the abyss of south-eastern Australia, and comments on the phylogeny of the family. Zootaxa, 4614 (2), $303-330$. https://doi.org/10.11646/zootaxa.4614.2.3

Zhou, Y., Wang, Y., Li, Y., Shen, C., Liu, Z., \& Wang, C. (2020) First report of Osedax in the Indian Ocean indicative of transoceanic dispersal through the Southern Ocean. Marine Biodiversity, 50, 4.

https://doi.org/10.1007/s12526-019-01034-x 